\title{
Adsorption of Propazine, Simazine and Bisphenol A on the Surface of Nanoparticles of Iron Oxide Nanoparticles of Carbon and Metallic Oxides
}

\author{
Matthewos Eshete*, Jerrano Bowleg, Selene G. Perales, Maxwell Okunrobo, Dominique Watkins, \\ Hattie Spencer
}

Department of Natural Sciences and Environmental Health, Mississippi Valley State University, Itta Bena, MS, USA

Email: *meshete@mvsu.edu

How to cite this paper: Eshete, M., Bowleg, J., Perales, S.G., Okunrobo, M., Watkins, D. and Spencer, H. (2018) Adsorption of Propazine, Simazine and Bisphenol A on the Surface of Nanoparticles of Iron Oxide Nanoparticles of Carbon and Metallic Oxides. Journal of Environmental Protection, 9, 13-24.

https://doi.org/10.4236/jep.2018.91002

Received: October 23, 2017

Accepted: January 9, 2018

Published: January 12, 2018

Copyright $\odot 2018$ by authors and Scientific Research Publishing Inc. This work is licensed under the Creative Commons Attribution International License (CC BY 4.0).

http://creativecommons.org/licenses/by/4.0/

\begin{abstract}
Simazine and propazine are selective triazine herbicides currently in use to control broad-leaved weeds and annual grasses around the world. Bisphenol A (BPA) is an industrial chemical used in the production of polycarbonate plastics often found in consumer goods, such as plastic containers, baby bottles etc. These synthetic compounds are known to increase the risk of cancer, cause adverse reproductive effect in reptiles, mammals, birds, humans, and lead to other health problems. They have become some of the principal agents of contamination in water bodies around the world through herbicide runoff, industrial waste and leaching. Some triazines such as atrazine are banned in most European countries for over ten years due to their adverse reproductive effect in mammals, birds and humans; however propazine and simazine are still in use around the world. The removal of these compounds from contaminated water is an exigent challenge. In this study, we investigated their affinity for the surface of nanoparticles (NPS) and standard metallic oxides in an effort to exploit the unique potential applications of NPS for water purification systems. We studied the adsorption of the two triazines and BPA on the surface of NPS of iron (III) oxide, NPS of carbon, bulk iron (III) oxide and aluminum oxide at $\mathrm{pH} 6$ and $\mathrm{pH} 8$ using UV-Visible spectroscopy. Result indicates that these compounds have different affinity towards the surface of metallic oxides and carbon at various pHs. In general, there is relatively high adsorption of some of these compounds on the surface of NPS compared to bulk particles. NPS of carbon have shown the highest affinity for all the three compounds. The lower $\mathrm{pH}$ was found to be favorable for all of the compounds except for BPA. BPA have shown high adsorption at $\mathrm{pH} 8$ than at $\mathrm{pH} 6$.
\end{abstract}




\section{Keywords}

Triazine, Adsorption of Nanoparticles, Nanoparticles of Iron Oxide, Nanoparticles of Carbon, Bisphenol A

\section{Introduction}

Surface, ground and drinking water contamination by various synthetic chemicals such as herbicides, pesticides, insecticides as well as other industrial chemicals has been a major problem throughout the world [1]-[10]. Especially as the need to grow more food increases, it becomes necessary to use more of these chemicals to increase output of food production. Millions of tons of these products are being used every year leading to an elevated level of contamination of water bodies through agricultural runoff and industrial effluent. Triazines are wide-spectrum pesticides used to control broad-leaved weeds and annual grassy weeds. Some triazines such as atrazine are banned in most European countries for more than ten years due to their presence in water system at high concentration which may have adverse reproductive effect in mammals, birds and humans. Triazines such as propazine and simazine are currently in use around the world. Various studies have shown triazines to be risk factors for different forms of cancers. Consuming high doses over long periods of time caused tremors, damage to the testes, kidneys, liver and thyroid and a decrease in sperm production in lab animals [11]-[24]. Bisphenol A (4,4'-(propane-2,2-diyl)diphenol) (BPA) is a well know synthetic compound that is used in the production of plastic containers such as food and beverage containers, baby bottles, water bottles, medical devises, baby toys and many other consumer products [25]. BPA is a source of water contamination that is known to enter water systems through leaching, direct waste disposal of consumer goods and from industrial waste. It has been detected in ground water, surface and drinking water [26] [27] [28] [29] [30]. It is a known endocrine disruptor and has been implicated in various adverse reproductive effects in birds, frogs, reptiles, fish and mammals. It has been linked to prostate, breast cancer, birth defects, miscarriages, and many other conditions [31]-[43]. The removal of these compounds from contaminated water has become a challenge and needs a unique approach. Studies have shown these environmental contaminants interact with the surface of materials, such as quartz, calcite, kaolinite, alumina, organic compost and nanoparticles, moreover these studies highlighted the potential use of these materials as environmental remediation [44] [45] [46] [47] [48]. Particles with the size range of $1 \mathrm{~nm}$ to 100 $\mathrm{nm}$ are called nanoparticles (NPS). They possess enhanced or altered physical, chemical and biological properties which make them superior in different applications than bulk particles. Correspondingly, there has been a dramatic increase in emerging new uses of NPS for various applications, including; medicine, biotechnology, antimicrobial activities, food, beverages, chemicals, communications, 
consumer goods and environmental remediation [49] [50] [51] [52] [53]. In this study, we investigated adsorption of simazine, propazine and BPA on the surface of NPS of iron (III) oxide, NPS of carbon, bulk iron (III) oxide and aluminum oxide. The effort is to exploit NPS' unique properties that can potentially be applied in water purification systems. In order to achieve these goal adsorption batch experiments were performed with $0.4 \mathrm{~g} / \mathrm{L}$ of NPS of $\mathrm{Fe}_{2} \mathrm{O}_{3}$, NPS of carbon, regular $\mathrm{Fe}_{2} \mathrm{O}_{3}$, or regular $\mathrm{Al}_{2} \mathrm{O}_{3}$ at $\mathrm{pH} 6$ and $\mathrm{pH} 8$ and UV-Visible spectroscopy was used to determine surface adsorption.

\section{Materials and Experimental Methods}

\subsection{Materials}

The two triazine herbicides, simazine and propazine and bisphenol A (Figure 1), iron (III) oxide Nanopowder, carbon nanopowder, aluminum oxide, and iron (III) oxide are all purchased form Sigma-Aldrich chemical company (St. Louis, MO). All chemicals used for this experiment were reagent grade. Spectronic GENESYS spectrophotometer from Thermo Electron Corporation (Madison, WI), New Brunswick I24 Bench top Incubator Shaker from VWR (Radnor, PA) and Fisher Marathon 26 KMR Centrifuge were used.

\subsection{Adsorption of Selective Triazine Herbicides and Bisphenol A on the Surface of Carbon Nanoparticles, Metallic Oxides and Nanoparticles of Metallic Oxides as Monitored by UV-Vis Spectroscopy}

Stock solution with appropriate concentration of the contaminants such as simazine, propazine and bisphenol A were prepared. Stock solution of iron (III) oxide, nanoparticles of iron (III) oxide, aluminum oxide, and nanoparticles of carbon were prepared to give a concentration of $0.4 \mathrm{~g} / \mathrm{L}$. Appropriate sample concentration was run in an UV-Visible spectrophotometer and the maximum<smiles>CC(C)Nc1nc(Cl)nc(NC(C)C)n1</smiles>

(a)<smiles>CCNc1nc(Cl)nc(NCC)n1</smiles>

(b)<smiles>CC(C)(c1ccc(O)cc1)c1ccc(O)cc1</smiles>

(c)

Figure 1. Chemical structure of Triazine herbicides and Bisphenol A: (a) Propazine, (b) Simazine and (c) Bisphenol A. 
absorption wavelength for simazine, propazine and bisphenol A were determined to be $227 \mathrm{~nm}, 222 \mathrm{~nm}$, and $285 \mathrm{~nm}$ respectively. Once the maximum absorption wavelength was determined for the individual contaminant, ten standard samples with concentrations from $10-160 \mu \mathrm{M}$ of contaminant were placed in an UV spectrophotometer to obtain standard curve for each individual samples. The standard curve was used to determine the adsorbed amount of adsorbates on the surface of the adsorbent. In each experiment, various ranges of concentrations of the individual contaminant was placed in an Erlenmeyer Flasks, and $10 \mathrm{ml}$ adsorbent solution $\left(\mathrm{Fe}_{2} \mathrm{O}_{3}, \mathrm{Al}_{2} \mathrm{O}_{3}, \mathrm{Fe}_{2} \mathrm{O}_{3}\right.$ nanoparticles, or carbon nanoparticles) at either $\mathrm{pH} 6$ or $\mathrm{pH} 8$; was added to each flask. The samples were placed in a shaker at room temperature for 17 hours and agitated with a speed of $170 \mathrm{rpm}$. In order to minimize photolytic activity, samples were left overnight in the incubator with no direct light. After 17 hours, the samples were centrifuged at $1000 \mathrm{rpm}$ for 15 minutes at room temperature and filtered with the help of vacuum filtration. After filtration, the UV absorption of each sample was measured at appropriate wavelength (for simazine, propazine and bisphenol A $227 \mathrm{~nm}, 222 \mathrm{~nm}$, and $285 \mathrm{~nm}$ respectively) with distilled water as baseline. Once the absorbance data was collected, it was used to determine the final concentration of the respective contaminants by using the equations derived from the standard curves; $\mathrm{y}=\mathrm{ax}+\mathrm{b}$. Where, $\mathrm{y}$ is absorbance, $\mathrm{a}$ is concentration and $b$ is a constant. The amount of adsorbed contaminant per gram of adsorbent was calculated as the difference between the initial concentration and the concentration at equilibrium using the equation; $q=\left(C_{o}-C_{e}\right)(M) \mathrm{V} / \mathrm{m}$. Where $\mathrm{Q}$ is the amount adsorbed molecule $(\mathrm{mg} / \mathrm{g}) . C_{o}$ is the initial concentration, $C_{e}$ is the concentration at equilibrium, $V$ is the volume of working solution, $M$ is the Molar Mass of contaminant and $\mathrm{m}$ is the mass of adsorbent added to the working solution. Weight in $\mathrm{mg}$ of respective contaminant/g of adsorbent versus concentration $(\mathrm{mM})$ or $(\mu \mathrm{M})$ were plotted to show the extent of binding.

\section{Results and Discussion}

Synthetic compounds, simazine, propazine and bisphenol A were used to study adsorption on the surface of adsorbent compounds, NPS of iron (III) oxide, NPS of carbon, bulk iron (III) oxide and aluminum oxide. Figure 2 shows the plot of surface coverage vs. concentration for adsorption of BPA on the surface of various adsorbent. BPA have been found to shown the highest biding on the surface of carbon NPS at pH 6 followed by aluminum oxide, iron (III) oxide and NPS of iron (III) oxide respectively. In Figure 3, the same trend was observed at $\mathrm{pH} 8$ for carbon NPS, aluminum oxide, while the NPS of iron (III) oxide showed higher surface adsorption than bulk iron (III) oxide. Moreover, the entire compound tested shown to have higher surface coverage by BPA at $\mathrm{pH} 8$ than at $\mathrm{pH}$ 6 . These phenomena could be explained based on the charge that can be developed on BPA due to the increase in $\mathrm{pH}$. The $\mathrm{pKa}$ value for BPA is 9.9 , as the $\mathrm{pH}$ gets closer to the pKa value more of the BPA exists as negatively charged ion and 


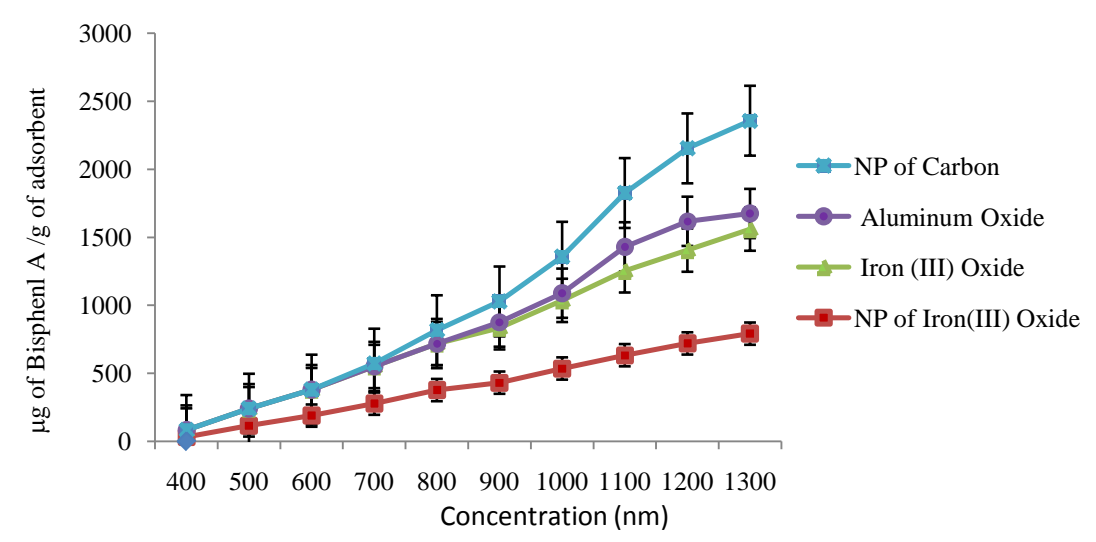

Figure 2. Plot of surface coverage vs. concentration for adsorption of bisphenol A on the surface of NPS of iron (III) oxide, NPS of carbon, regular iron (III) oxide, and aluminum oxide at $\mathrm{pH} 6$.

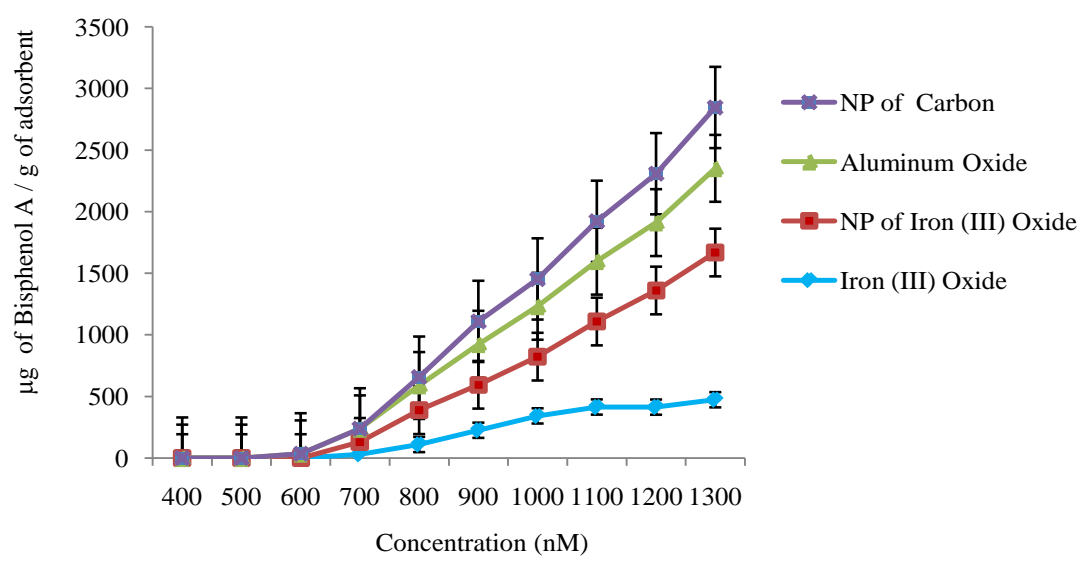

Figure 3. Plot of surface coverage vs. concentration for adsorption of bisphenol A on the surface of NPS of iron (III) oxide, NPS of carbon, regular iron (III) oxide, and aluminum oxide at $\mathrm{pH} 8$.

this allows better interaction with the surface of the adsorbent. Figure 4 and Figure 5 show adsorption of propazine on the surface of all the adsorbents tested. Propazine has the highest adsorption on the surface of carbon NPS followed by NPS of iron (III) oxide, aluminum oxide and NPS of iron (III) oxide at both pH 6 and pH 8. The same trend can be seen for simazine at both pH 6 and 8 , only in this case the adsorption on the surface of aluminum is better than NPS of iron (III) oxide and iron (III) oxide (Figure 6 and Figure 7). In general, NPS expected to have more reaction site available for the interaction due to large surface area to mass ratio and this may explain why we see better surface coverage on NPS than the corresponding bulk particles. The fact that there were relatively higher adsorption on the surface of metallic oxides at $\mathrm{pH} 6$ than at $\mathrm{pH} 8$ can be explained due to the increase in the number of adsorption sites on the surface of metallic oxides at lower $\mathrm{pH}$ compared to higher $\mathrm{pH}$, i.e. more of $\mathrm{M}-\mathrm{OH}_{2}^{+}$ presents at $\mathrm{pH} 6$ and more of $\mathrm{M}-\mathrm{OH}$ presents at $\mathrm{pH}$ 8. Charge distributions on the surface of metallic oxides are shown below at higher and lower $\mathrm{pHs}$ ). 

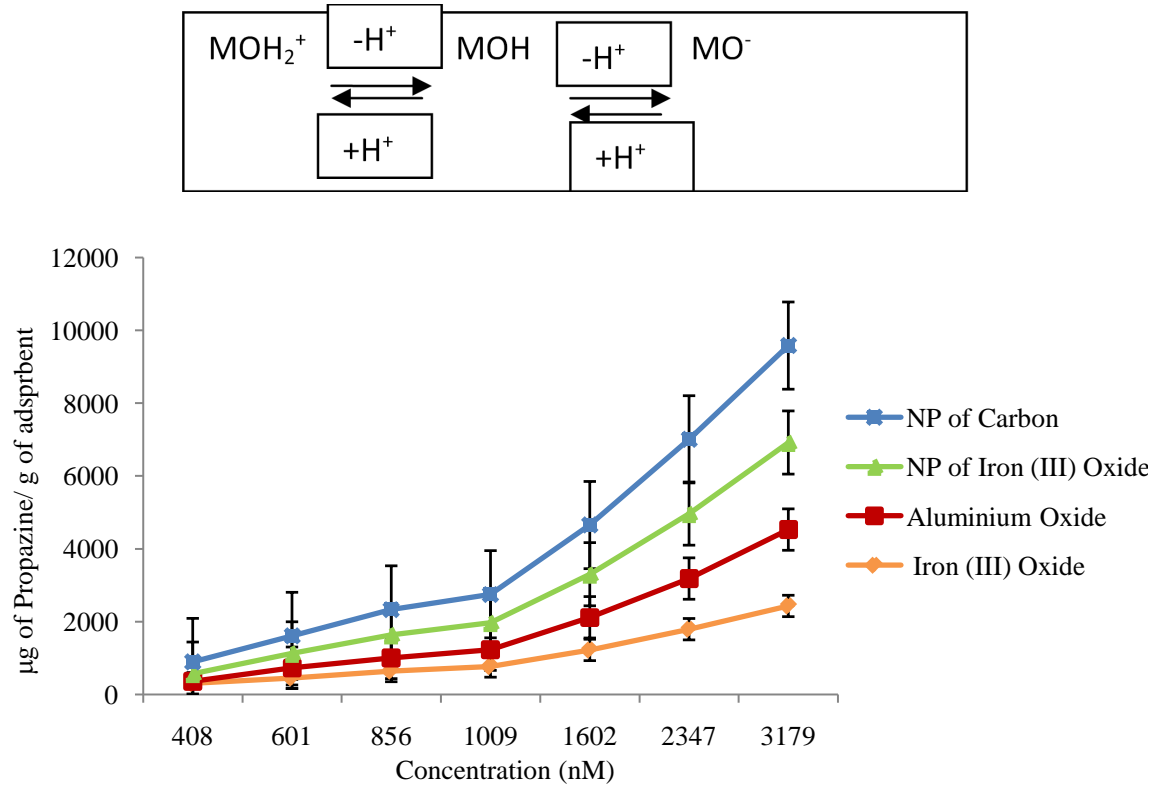

Figure 4. Plot of surface coverage vs. concentration for adsorption of propazine on the surface of NPS of iron (III) oxide, NPS of carbon, regular iron (III) oxide, and aluminum oxide at $\mathrm{pH} 6$.

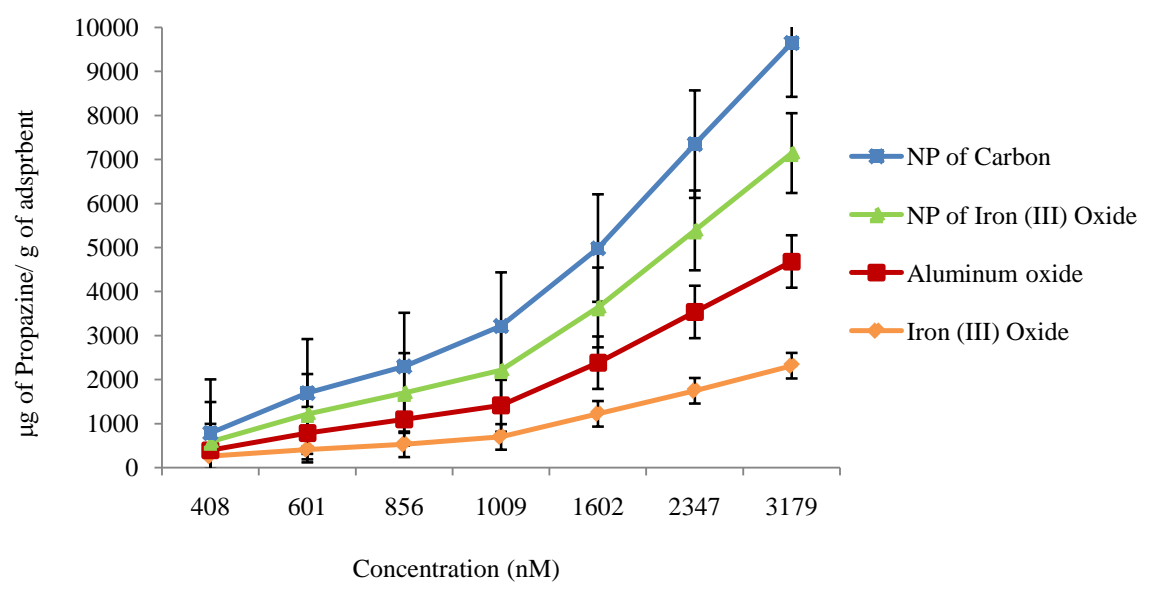

Figure 5. Plot of surface coverage vs. concentration for adsorption of propazine on the surface of NPS of iron (III) oxide, NPS of carbon, regular iron (III) oxide, and aluminum oxide at $\mathrm{pH} 8$.

\section{Conclusion}

The adsorption properties of metallic oxides depend on the charge, surface area, pore-size and characteristics of the surface. In general, adsorption on surface of metallic oxides can be explained using two mechanisms. The first is availability of adsorption site and the second mechanism is electrostatic attraction due to surface charge. At a lower $\mathrm{pH}$ surface of metallic oxide expected to have more available reaction site. However, our result shows favorable adsorption of BPA at the higher $\mathrm{pH}$. This may be an indication that the charge developed on the BPA plays a major role in creating electrostatic interaction than the available binding 


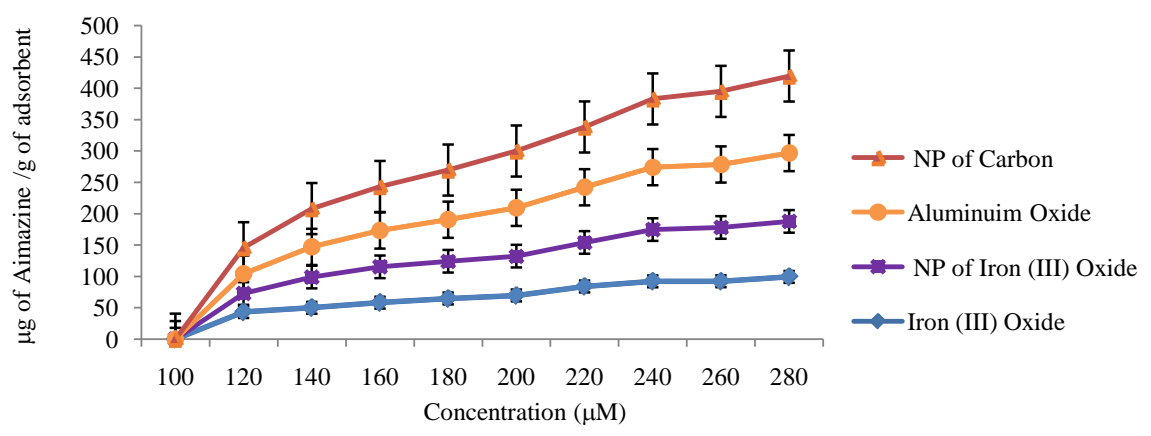

Figure 6. Plot of surface coverage vs. concentration for adsorption of simazine on the surface of NPS of iron (III) oxide, NPS of carbon, regular iron (III) oxide, and aluminum oxide at $\mathrm{pH} 6$.

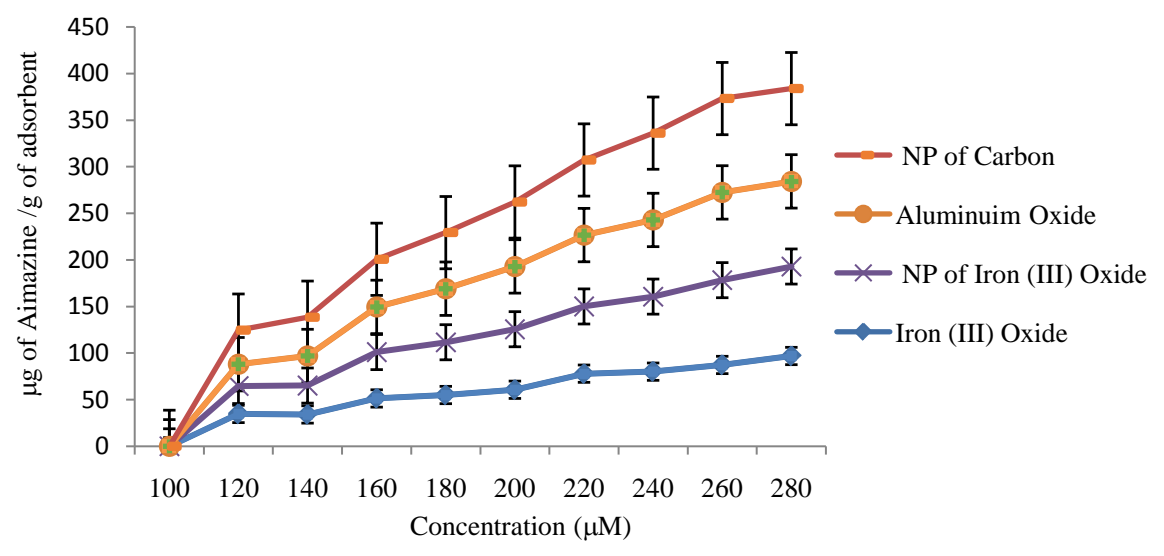

Figure 7. Plot of surface coverage vs. concentration for adsorption of simazine on the surface of NPS of iron (III) oxide, NPS of carbon, regular iron (III) oxide, and aluminum oxide at $\mathrm{pH} 8$.

site on the surface of metallic oxides that could be developed at a lower $\mathrm{pH}$. For propazine and simazine, adsorption capacity and affinity increased at $\mathrm{pH} 6$ which is consistent with the increase in the available reaction site on the surface of metallic oxides at lower $\mathrm{pH}$ than at higher $\mathrm{pH}$. On the other hand, NPS of carbon found to be the best adsorbent of all the compounds tested at both $\mathrm{pHs}$. In this case, it could be because that the unique properties of NPS are at play, i.e. the large surface area to mass ratio for NPS compared to the bulk particles. In general, NPS have shown to have better adsorption for the compound tested, moreover we have shown that $\mathrm{pH}$ of the solution could affect the interaction. Future study that includes various reaction conditions, such as ionic strength and presence of multiple adsorbent and adsorbates could provide more information about the interaction and open up ways in using NPS for water purification systems.

\section{Acknowledgements}

The authors would like to express their appreciation for the Department of Natural Sciences and Environmental Health at Mississippi Valley State University 
and the former Department Chair Dr. Lewis Hall for facilitating the research. The work was funded by Delta Research \& Cultural Institute and Mississippi Valley state University Faculty Development Grants.

\section{References}

[1] Kuster, M., López de Alda, M.J., Barata, C., Raldúa, D. and Barceló, D. (2008) Analysis of 17 Polar to Semi-Polar Pesticides in the Ebro River Delta during the Main Growing Season of Rice by Automated On-Line Solid-Phase Extraction-Liquid Chromatography-Tandem Mass Spectrometry. Talanta, 75, 390-401. https://doi.org/10.1016/j.talanta.2007.11.027

[2] Aguilar, J.A.P., Andreu, V., Campo, J., Picó, Y. and Masiá, A. (2017) Pesticide Occurrence in the Waters of Júcar River, Spain from Different Farming Landscapes. Science of the Total Environment, 607-608, 752-760. https://doi.org/10.1016/j.scitotenv.2017.06.176

[3] Ritter, W.F. (2008) Pesticide Contamination of Ground Water in the United States -A Review. Journal of Environmental Science and Health, Part B, 25, 1-29. https://doi.org/10.1080/03601239009372674

[4] Konstantinou, I.K., Hela, D.G. and Albanis, T.A. (2006) The Status of Pesticide Pollution in Surface Waters (Rivers and Lakes) of Greece. Part I. Review on Occurrence and Levels. Environmental Pollution, 141, 555-570. https://doi.org/10.1016/j.envpol.2005.07.024

[5] Kolpin, D.W., Kalkhoff, S.J., Goolsby, D.A., Sneck-Fahrer, D.A. and Thurman, E.M. (1997) Occurrence of Selected Herbicides and Herbicide Degradation Products in Iowa's Ground Water. Groundwater, 35, 679-688. https://doi.org/10.1111/j.1745-6584.1997.tb00134.x

[6] Rocha, C., Pappas, E.A. and Huang, C.H. (2008) Determination of Trace Triazine and Chloroacetamide Herbicides in Tile-Fed Drainage Ditch Water Using Solid-Phase Microextraction Coupled with GC-MS. Environmental Pollution, 152, 239-244. https://doi.org/10.1016/j.envpol.2007.04.029

[7] Devault, D.A., Merlina, G., Lim, P., Probst, J.-L. and Pinelli, E. ( 2007) Multi-Residues Analysis of Pre-Emergence Herbicides in Fluvial Sediments: Application to the Mid-Garonne River. Journal of Environmental Monitoring, 9, 1009-1017. https://doi.org/10.1039/b708454b

[8] Pereira, W.E. and Hostettler, F.D. (1993) Nonpoint Source Contamination of the Mississippi River and Its Tributaries by Herbicides. Environmental Science \& Technology, 27, 1542-1552. https://doi.org/10.1021/es00045a008

[9] Belden, J.B., Gilliom, R.J., Martin, J.D. and Lydy, M.J. (2007) Relative Toxicity and Occurrence Patterns of Pesticide Mixtures in Streams Draining Agricultural Watersheds Dominated by Corn and Soybean Production. Integrated Environmental Assessment and Management, 3, 90-100. https://doi.org/10.1002/ieam.5630030108

[10] Köck-Schulmeyer, M., Ginebreda, A., Postigo, C., Garrido, T., Fraile, J., de Alda, M.L. and Barceló, D. (2014) Four-Year Advanced Monitoring Program of Polar Pesticides in Groundwater of Catalonia (NE-Spain). Science of the Total Environment, 470-471, 1087-1098. https://doi.org/10.1016/j.scitotenv.2013.10.079

[11] Kettles, M.K., Browning, S.R., Prince, T.S. and Horstman, S.W. (1997) Triazine Herbicide Exposure and Breast Cancer Incidence: An Ecologic Study of Kentucky Counties. Environmental Health Perspectives, 105, 1222-1227.

https://doi.org/10.1289/ehp.971051222 
[12] Peterson, H.G., Boutin, C., Martin, P.A., Freemark, K.E., Ruecker, N.J. and Moody, M.J. (1994) Aquatic Phyto-Toxicity of 23 Pesticides Applied at Expected Environmental Concentrations. Aquatic Toxicology, 28, 275-292.

https://doi.org/10.1016/0166-445X(94)90038-8

[13] Ricart, M., Guasch, H., Barceló, D., Brix, R., Conceição, M.H., Geiszinger, A., deAlda, M.J.L., López-Doval, J.C., Muñoz, I., Postigo, C., Romaní, A.M., Villagrasa, M. and Sabater, S. (2010) Primary and Complex Stressors in Polluted Mediterranean Rivers: Pesticide Effects on Biological Communities. Journal of Hydrology, 383, 52-61. https://doi.org/10.1016/j.jhydrol.2009.08.014

[14] Schuler, L.J., Trimble, A.J., Belden, J.B. and Lydy, M.J. (2005) Joint Toxicity of Triazine Herbicides and Organophosphate Insecticides to the Midge Chironomus tentans. Archives of Environmental Contamination and Toxicology, 49, 173-17. https://doi.org/10.1007/s00244-004-0224-8

[15] Dich, J., Zahm, S.H., Hanberg, A. and Adami, H.-O. (1997) Cancer Causes \& Control. Pesticides and Cancer, 8, 420-443.

[16] Swan, S.H., Kruse, R.L., Liu, F., Barr, D.B., Drobnis, E.Z., Redmon, J.B., Wang, C., Brazil, C. and Overstreet, J.W. (2003) Semen Quality in Relation to Biomarkers of Pesticide Exposure. Environmental Health Perspectives, 111, 1478-1484.

[17] Aktar, W., Sengupta, D. and Chowdhury, A. (2009) Impact of Pesticides Use in Agriculture: Their Benefits and Hazards. Interdisciplinary Toxicology, 2, 1-12. https://doi.org/10.2478/v10102-009-0001-7

[18] Arufe, M.I., Arellano, J., Moreno, M.J. and Sarasquete, C. (2004) Toxicity of a Commercial Herbicide Containing Terbutryn and Triasulfuron to Seabream (Sparus aurata L.) Larvae: A Comparison with the Microtox Test. Ecotoxicology and Environmental Safety, 59, 209-216. https://doi.org/10.1016/j.ecoenv.2003.12.010

[19] Petrelli, G. and Mantovani, A. (2002) Environmental Risk Factors and Male Fertility and Reproduction. Contraception, 65, 297-300. https://doi.org/10.1016/S0010-7824(02)00298-6

[20] De Roos, A.J., Zahm, S.H., Cantor, K.P., Weisenburger, D.D., Holmes, F.F., Burmeister, L.F. and Blair, A. (2003) Integrative Assessment of Multiple Pesticides as Risk Factors for Non-Hodgkin's Lymphoma among Men. Occupational and Environmental Medicine, 60, e11. https://doi.org/10.1136/oem.60.9.e11

[21] Stara, A., Machova, J. and Velisek, J. (2012) Effect of Chronic Exposure to Simazine on Oxidative Stress and Antioxidant Response in Common Carp (Cyprinus carpio L.). Environmental Toxicology and Pharmacology, 33, 334-343. https://doi.org/10.1016/j.etap.2011.12.019

[22] Velisek, J., Stara, A., Kolarova, J. and Svobodova, Z. (2011) Biochemical, Physiological and Morfological Responses in Common Carp (Cyprinus carpio L.) after Long-Term Exposure to Terbutryn in Real Environmental Concentration. Pesticide Biochemistry and Physiology, 100, 305-313. https://doi.org/10.1016/j.pestbp.2011.05.004

[23] MacLennan, P.A., Delzell, E., Sathiakumar, N., Myers, S.L., Cheng, H., Grizzle, W., Chen, V.W. and Wu, X.C. (2002) Cancer Incidence among Triazine Herbicide Manufacturing Workers. Journal of Occupational and Environmental Medicine, 44, 1048-1058.

[24] Zhu, X.-W., Liu, S.-S., Ge, H.-L. and Liu, Y. (2009) Comparison between the Short-Term and the Long-Term Toxicity of Six Triazine Herbicides on Photobacteria Q67. Water Research, 43, 1731-1739. https://doi.org/10.1016/j.watres.2009.01.004 
[25] Staples, C.A., Dorn, P.B., Klecka, G.M., O’Block, S.T. and Harris, L.R. (1998) A Review of the Environmental Fate, Effects, and Exposures of Bisphenol-A. Chemosphere, 36, 2149-2173. https://doi.org/10.1016/S0045-6535(97)10133-3

[26] Sánchez-Avila, J., Fernandez-Sanjuan, M., Vicente, J. and Lacorte, S. (2011) Development of a Multi-Residue Method for the Determination of Organic Micropollutants in Water, Sediment and Mussels using Gas Chromatography-Tandem Mass Spectrometry. Journal of Chromatography A, 1218, 6799-6811.

https://doi.org/10.1016/j.chroma.2011.07.056

[27] Rocha, M.J., Cruzeiro, C. and Rocha, E. (2013) Quantification of 17 Endocrine Disruptor Compounds and Their Spatial and Seasonal Distribution in the Iberian Ave River and Its Coastline. Toxicological \& Environmental Chemistry, 95, 386-399. https://doi.org/10.1080/02772248.2013.773002

[28] Staniszewska, M., Falkowska, L., Grabowski, P., Kwasniak, J., Mudrak-Cegiolka, S., Reindl, A.R., Sokolowski, A., Szumilo, E. and Zgrundo, A. (2014) Bisphenol A, 4-Tert-Octylphenol, and 4-Nonylphenol in the Gulf of Gdansk (Southern Baltic). Archives of Environmental Contamination and Toxicology, 67, 335-347. https://doi.org/10.1007/s00244-014-0023-9

[29] Colin, A., Bach, C., Rosin, C., Munoz, J.F. and Dauchy, X. (2014) Is Drinking Water a Major Route of Human Exposure to Alkylphenol and Bisphenol Contaminants in France? Archives of Environmental Contamination and Toxicology, 66, 86-99. https://doi.org/10.1007/s00244-013-9942-0

[30] Corrales, J., Kristofco, L.A., Steele, W.B., Yates, B.S., Breed, C.S., Williams, E.S. and Brooks, B.W. (2015) Global Assessment of Bisphenol A in the Environment: Review and Analysis of Its Occurrence and Bioaccumulation. Dose Response, 13, 1559325815598308. https://doi.org/10.1177/1559325815598308

[31] Lahnsteiner, F., Berger, B., Kletz, M. and Weismann, T. (2005) Effect of Bisphenol A Onmaturation and Quality of Semen and Eggs in the Brown Trout, Salmo trutta f. fario. Aquatic Toxicology, 75, 213-224. https://doi.org/10.1016/j.aquatox.2005.08.004

[32] Oehlmann, J., Schulte-Oehlmann, U., Bachmann, J., Oetken, M., Lutz, I., Kloas, W. and Ternes, T.A. (2006) Bisphenol A Induces Superfeminization in the Ramshorn Snail Marisa Cornuarietis (Gastropoda: Prosobranchia) at Environmentally Relevant Concentrations. Environmental Health Perspectives, 114, 127-133. https://doi.org/10.1289/ehp.8065

[33] Lemos, M.F.L., van Gestel, C.A.M. and Soares, A.M.V.M. (2010) Reproductive Toxicity of the Endocrine Disrupters Vinclozolin and Bisphenol A in the Terrestrial Isopod Porcellio scaber (Latreille, 1804). Chemosphere, 78, 907-913. https://doi.org/10.1016/j.chemosphere.2009.10.063

[34] Lemos, M.F.L., van Gestel, C.A.M. and Soares, A.M.V.M. (2009) Endocrine Disruption in a Terrestrial Isopod under Exposure to Bisphenol A and Vinclozolin. Journal of Soils and Sediments, 9, 492-500. https://doi.org/10.1007/s11368-009-0104-y

[35] Biggers, W.J. and Laufer, H. (2004) Identification of Juvenile Hormone-Active Alkylphe-Nols in the Lobster Homarus americanus and in Marine Sediments. The Biological Bulletin, 206, 13-24. https://doi.org/10.2307/1543194

[36] Kashiwagi, K., Utsumi, K., Kashiwagi, K., Ohta, S., Sugihara, K., Hanada, H. and Kitamura, S. (2008) Effects of Endocrine Disrupting Chemicals on Amphibian Metamorphosis and Mitochondrial Membrane Permeability Transition. Journal of Health Science, 54, 273-280. https://doi.org/10.1248/jhs.54.273 
[37] Kloas, W., Lutz, I. and Einspanier, R. (1999) Amphibians as a Model to Study Endocrinedisruptors: II. Estrogenic Activity of Environmental Chemicals in Vitro Andin Vivo. Science of the Total Environment, 225, 59-68.

https://doi.org/10.1016/S0048-9697(99)80017-5

[38] Stoker, C., Rey, F., Rodriguez, H., Ramos, J.G., Sirosky, P., Larrier, A., Luque, E.H. and Munoz-de-Toroa, M. (2003) Sex Reversal Effects on Caiman latirostris Exposed to Environmentally Relevant Doses of the Xenoestrogen Bisphenol A. General and Comparative Endocrinology, 133, 287-296. https://doi.org/10.1016/S0016-6480(03)00199-0

[39] Furuya, M., Sasaki, F., Hassanin, A.M.A., Kuwahara, S. and Tsukamoto, Y. (2002) Effects of Bisphenol-A on the Growth of Comb and Testes of Male Chicken. Canadian Journal of Veterinary Research, 67, 68-71.

[40] Richter, C.A., Birnbaum, L.S., Farabollini, F., Newbold, R.R., Rubin, B.S., Talsness, C.E., Vandenbergh, J.G., Walser-Kuntz, D.R. and vom Saal, F.S. (2007) In Vivo Effects of Bisphenol A in Laboratory Rodent Studies. Reproductive Toxicology, 24, 199-224. https://doi.org/10.1016/j.reprotox.2007.06.004

[41] Hunt, P.A., Susiarjo, M., Rubio, C. and Hassold, T. (2009) The Bisphenol A Experience: A Primer for the Analysis of Environmental Effects on Mammalian Reproduction. Biology of Reproduction, 81, 807-813. https://doi.org/10.1095/biolreprod.109.077008

[42] Flint, S., Markle, T., Thompson, S. and Wallace, E. (2012) Bisphenol A Exposure, Effects, and Policy: A Wildlife Perspective. Journal of Environmental Management, 104, 19-34. https://doi.org/10.1016/j.jenvman.2012.03.021

[43] Rochester, J. (2013) Bisphenol A and Human Health: A Review of the Literature. Reproductive Toxicology, 42, 132-155. https://doi.org/10.1016/j.reprotox.2013.08.008

[44] Wei, Z., Guob, M., Chowa, T., Bennetta, D.N. and Rajagopalana, N. (2010) Sorption Properties of Greenwaste Biochar for Two Triazine Pesticides. Journal of Hazardous Materials, 181, 121-126. https://doi.org/10.1016/j.jhazmat.2010.04.103

[45] Clausen, L., Fabricius, I. and Madsen, L. (2001) Adsorption of Pesticides onto Quartz, Calcite, Kaolinite, and a-Alumina. Journal of Environmental Quality, 30, 846-857. https://doi.org/10.2134/jeq2001.303846x

[46] José, F., Nuria, V., Ginés, N., Gabriel, P.-L. and Simón, N. (2014) Assessment of Agro-Industrial and Composted Organic Wastes for Reducing the Potential Leaching of Triazine Herbicide Residues through the Soil. Science of the Total Environment, 493, 124-132. https://doi.org/10.1016/j.scitotenv.2014.05.098

[47] Macek, T., Macková, M. and Káš, J. (2000) Exploitation of Plants for the Removal of Organics in Environmental Remediation. Biotechnology Advances, 18, 23-34. https://doi.org/10.1016/S0734-9750(99)00034-8

[48] He, Z., Wang, P., Liu, D. and Zhou, Z. (2014) Hydrophilic-Lipophilic Balanced Magnetic Nanoparticles: Preparation and Application in Magnetic Solid-Phase Extraction of Organochlorine Pesticides and Triazine Herbicides in Environmental Water Samples. Talanta, 127, 1-8. https://doi.org/10.1016/j.talanta.2014.03.074

[49] Esakkimuthu, T., Sivakumar, D. and Akila, S. (2014) Application of Nanoparticles in Waste Water Treatment. Pollution Research, 33, 567-571.

[50] Justin, T.S. and Thomas, J.W. (2012) Antimicrobial Applications of Nanotechnology: Methods and Literature. International Journal of Nanomedicine, 7, 2767-2781.

[51] Jain, P. and Pradeep, T. (2005) Potential of Silver Nanoparticle-Coated Polyurethane Foam as an Antibacterial Water Filter. Biotechnology and Bioengineering, 90, 59-63. https://doi.org/10.1002/bit.20368 
[52] Consumer Products Inventory (2013) Projection Emerging Nanotechnologies. http://www.nanotechproject.org/cpi

[53] Jayanth, P. and Vinod, L. (2003) Biodegradable Nanoparticles for Drug and Gene Delivery to Cells and Tissue. Advanced Drug Delivery Review, 55, 329-347. 